\title{
THE INFLUENCE FACTORS OF TEACHER PERFORMANCE
}

\author{
Suryadi ${ }^{1}$ \\ Agustin HP2 \\ Hari Sukarno ${ }^{3}$
}

\author{
Higher Education of Economic Mandala \\ e-mail: surya_ana10@yahoo.co.id
}

\begin{abstract}
The purpose of the research was to analyze and examine the influence of the principal managerial competence, motivation and work discipline on teacher performance, both partially and simultaneously. This research was explanatory survey research. The population of the research was the whole teacher of SMA Negeri 1 Cluring, Banyuwangi totaling 39 teachers. The sample used was 31 teachers, chosen by purposive sampling technique. The preparation of the instrument was made in the form of a questionnaire, with a scale of 1-5 answers, consisting of 37 items. The instrument items used to collect data are those that meet the requirements of construct analysis and have valid status. Its reliability is calculated by the Cronbach's Alpha technique. Data collection methods used in this research were observation, interview, questionnaire, and through documentation. Data analysis used multiple linear regression. Based on the results of research and analysis of the data, it showed that the principal managerial competence, motivation and work discipline influenced to the teacher performance significantly both partially and simultaneously. Test results partially were evidenced by the significant value to the variable of the managerial competence that was 0.048 , then the significant value of motivation variable was 0.014 and for work discipline was 0.016 . So the amount of significance value was smaller than 0.05 . The results of the test simultaneously were demonstrated by the value of the principal managerial competence, motivation and work discipline to the teacher performance that was 0.000 . Therefore, the significance value was smaller than 0.05 .
\end{abstract}

Keywords: The Principal Managerial Competence, Motivation, Work Discipline, Teacher Performance

\section{INTRODUCTION}

The autonomous areas are imposed in Indonesia through Act No. 23 of 2014 on local governance. Education is one of the parts that are included in these changes, which the school fully authorized to manage themselves. The principal, teachers, educational personnel, supervisors, and the society are involved in achieving the vision and mission of the school. The Principal, with a good competence and effective managerial, is expected to boost the spirit and passion of the work of teachers, administrative personnel and employees, and provides motivation for those in charge. The principal at least has a role and function as Educator, Manager, Administrator, Supervisor, Leader, Innovator and Motivator (EMASLIM) (Mulyasa, 2009:98). According to the Act No. 22015 about teachers and professors at chapter I article 1 states that the teacher is a professional 
educator with the main task of educating, teaching, guiding, directing, train, assess, and evaluate learners in the early childhood education path of formal education, elementary education, and secondary education. Professional teacher duties include (1) carry out a quality learning, assessing and evaluating learning outcomes, (2) improve the academic qualification and competence on an ongoing basis with the development of science, and (3) upholding the legislation law and the code of ethics of the teachers as well as the values of religion and ethics and are able to maintain, cultivate unity and the unity of the nation. To realize professional teachers need the motivation of working so that the performance of the teachers can be increased.

The Research of Sutikno (2015) concluded that motivation influenced significantly on performance SMK Negeri 5 Jember teachers. According to Husein (2002:274), motivation is encouragement, effort and desire that exists in human resources as well as giving activate, directing behavior in the performance of tasks in environmental work. Teacher who has high motivation will work hard to carry out the duty carefully and always use the procedure for appropriate learning conditions which is optimally and the best one. Factors that affect the performance of the teacher in order to increase the motivation of working also influenced other than influenced by discipline teachers. Meta (2013) concluded that the performance of the employees affected by a work discipline. According to Rivai (2004: 444) work discipline is a tool used by managers to communicate with employees so that they are willing to change a behavior and as an effort to increase someone awareness and willingness to obey all company rules and prevailing social norms. One of the characteristics of the teacher's performance is work discipline because it relates to obedience and adherence to the applicable rules or regulations, the percentage of attendance, also related to the decline in work productivity which has a major influence on education. This happens because the existence of teachers is still dominant in the learning process both inside and outside the classroom.

In fact, there are still many problems in SMA Negeri 1 Cluring that must be addressed with regard to managerial competencies of the principal work, motivation and discipline teachers work to achieve the vision and mission of the school which produced a good and qualified graduates.

It can be seen from the absence (presence/absence) of teachers, there are still no results of teacher work performance in the competition activities at the district, provincial and national level, the ability of the Principal to influence teacher performance is not optimal and the training program for the development of frequency teacher competencies is still low.

Thus, to improve teacher performance, a school principal needs managerial competence, motivation and good work discipline. Activities on the study of managerial competence, motivation and work discipline to improve teacher performance are very important to do.

Based on the descriptions that have been explained above, so this research aims to analyze the influence of the principal managerial competence, motivation and work discipline on teacher performance both partially and simultaneously.

\section{Theoretical Framework and Hypothesis}

Dharma (2009:102) defines competence as what is brought by someone into their work in the form of different types and levels of behavior. According to the Law of the Republic of Indonesia No. 14 of 2005 concerning teachers and lecturers 
stated that competence is a set of knowledge, skills, and behaviors that must be possessed, appreciated, and mastered by teacher and lecturer in performing the professional duties. Referring to the opinion of experts as above, then competence can be defined as something or an idea of what should be done by a person in carrying out a job, in the form of activities, behaviors and results that can be shown and demonstrated.

Managerial comes from the manager which means leader. According to Fattah (1999:13) managerial practice is an activity performed by managers. It is added by Siagian (1996:63) who suggests that the managerial skill is the skill of moving others to work properly. So it can be interpreted that managerial skill is the ability that is owned by someone to move the others in utilizing human resources (HR) and other resources that exist in achieving organizational goals effectively and efficiently.

The Principal is an additional position or assignment from a teacher. Principal positions can be likened to a manager in a company or organization. According to Wahjosumidjo (2005: 83) the Principal is a functional staff teacher who is given the task to lead a school where the teaching and learning process is organized, or where there is interaction between the teacher who gives lessons and students who receive lessons. Meanwhile, according to Mulyasa (2009: 24) the Principal is one of the components of education that plays the most important role in improving the quality of education.

From expert opinion, it can be stated that the principal is a functional person who plays a role in improving the quality of education, besides the principal is also in charge of the implementation of education, school administration, coaching educators, supervisors at the schools he leads and maintenance of facilities and infrastructure.
Some of the Principal roles in a new paradigm of management education are as follows (Mulyasa, 2009:98)
a. Principal as educator
b. Principal as Manager
c. Principal as administrator
d. Principal as supervisor
e. Principal as leader
f. Principal as innovator
g. Principal as a motivator

In carrying out the daily activities, a teacher really need a very strong motivation so that teaching and learning activities can run well and smoothly according to the objectives to be achieved. According to Sutikno (2015), the motivation of teacher can be interpreted as an encouragement that exists both from within a teacher and from around him which causes the teacher to have a strong desire to work and fulfill his duties as a teacher in order to achieve the goals of his educating activities. Therefore the motivation of the teacher can be interpreted as an encouragement or stimulus that exists both from within or outside the teacher to create excitement and fulfill his duties as a teacher as a teacher and educator in order to achieve the goals or aims of teaching and learning activities in school.

Two-factor theory of motivation maintenance which are developed by Herzberg in Syahdan (1996:22) suggests that there are two factors that influence the employment conditions, namely: (1) satisfaction factor (motivation factor), also known as satisfier or intrinsic motivation, (2) maintenance factor, also known as dissatisfier or extrinsic motivation.

Satisfaction factor is a driving factor for achievement that comes from within the person concerned which includes: (1) job satisfaction itself, (2) achievements, (3) opportunities for advancement, recognition of others (5) career development possibilities. 
To achieve the implementation of the work of each employee, we need a leader who always tries to encourage his subordinates to be more qualified to do the job in order to achieve maximum possible achievement. It is important because the accomplishments are achieved by each employee not create a sense of pride in the person concerned, but also profitable for the organization in an effort to increase its productivity.

Hasibuan (2006:193) argue that discipline is the awareness and willingness of someone adhering to all company regulations and prevailing social norms. While according to Fathoni (2006:172), discipline is an attitude of awareness and the willingness of someone to obey all the rules of organization and social norms in force.

Based on the above understanding, it can be stated that the discipline of work is an attitude, behavior, and actions of the teacher in accordance with the rules both written and unwritten, and when violating happen there will be sanctions over that offense to achieve the organization goals.

Tu'u (2004:38) suggested a few things that can be affected by discipline, namely:

1) Structuring life together

2) Developing personality

3) Training personality

4) Forcing function

5) Punishment function

6) Creating function

Sinungan (1997:145-146) states the characteristics of the discipline are:

1) the existence of a strong desire to fully implement what has become the norm, ethics and rules that apply in society;

2) existence of the controlled behavior;

3) presence of obedience.

According to Soejono (1997:67), indicators of the work discipline are:

1) timeliness;

2) using office equipment properly;
3 high responsibility;

4) adherence to the rules of the office.

The application of the work discipline in the work environment will initially be felt heavily by the employees at first, but when continuously enacted it will become a habit, and discipline will not become a heavy burden for employees. This discipline needs to be applied in the work environment, because it has been mentioned above that the discipline is not born automatically, but it needs guidance in upholding the work discipline.

Based on the theory above, the component used by researcher in this study were: 1) timeliness. 2) awareness at work. 3) obedience to the rules. The components were used in this research because it pertains to research on the work discipline and factors that influences as well as an indicator of work discipline itself.

According to Sulistyorini (2001:28) performance is the success rate of a person or group of people in carrying out the duties and responsibilities as well as the ability to achieve the goals and standards that have been set. According to Usman (1990:4) the teacher is a position or profession who has the expertise to educate, teach and train students to develop students themselves and be able to adapt to the environment.

Based on several definitions above, it can be inferred about the definition of a teacher performance is as a result of the work or the activities of a teacher in the discharge of his duties in managing the learning activities in the quality and quantity within an organization (school) to achieve the goals and standards that have been set.

In its implementation the performance of the teacher or education staff can be measured using five aspects that can be used as measurement dimensions delivered by Mitchell quoted by Mulyasa (2009:138), namely:

1. Quality of Work 
2. Promptness (timeliness)

3. Initiative

4. Capability

5. Communication

Based on the regulation of the Minister of national education of Republic Indonesia No. 16 of 2007 about the standard academic qualification and competence of teacher, it is explained that the standards of academic qualifications and teacher competencies are fully developed from 4 main competencies, namely: 1) pedagogic competence, 2) personality competence, 3) social competence and 4) professional competence.

\section{The Conceptual Framework}

This conceptual framework is as a whole illustrate the influence of the principal managerial competence (Komman), motivation (Motiv), work and discipline work (Dis) against performance (Kiner). Based on the descriptions, the relationships between variables influence in this research as a whole is described in Figure 2.1.

\section{H 4}

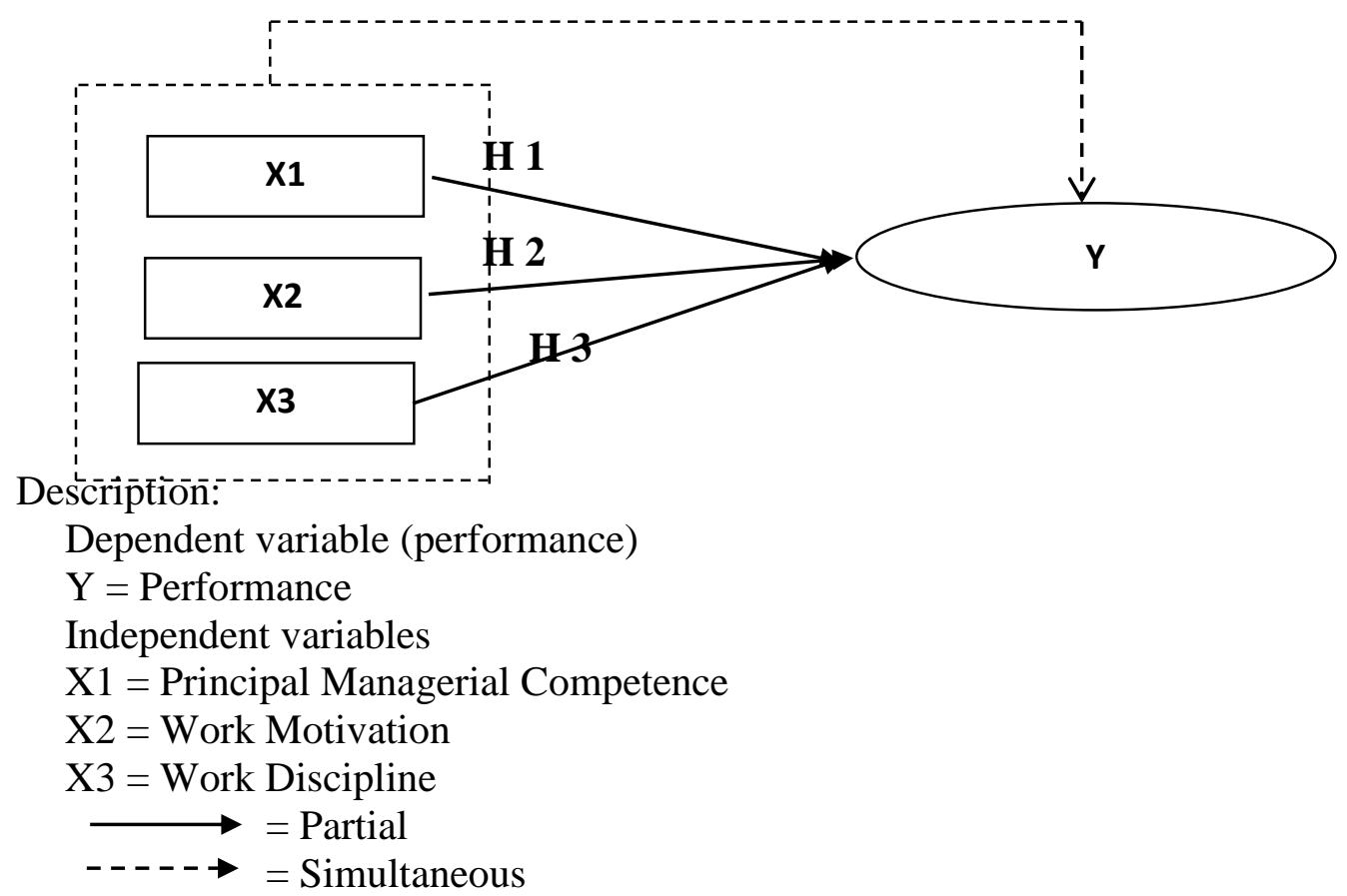

Figure 2.1. The Conceptual Framework

\section{The Hypothesis}

The hypothesis is a conjecture or statement expressed in declarative of the answer to a problem. The hypothesis in this study refers to earlier research and the study of the theory is as follows:

1) Based on that explanation, it can be formulated the hypothesis that the principal managerial competence partially has a significant effect on performance.
2) Based on that explanation, it can be formulated the hypothesis that work motivation partially has a significant effect on performance.

3) Based on that explanation, it can be formulated the hypothesis that work discipline partially has a significant effect on performance.

4) Based on the explanation, it may be formulated the hypothesis that the principal 
managerial competence, motivation and work disciplines simultaneously have a significant effect on performance.

\section{RESEARCH METHODS}

This research was held at SMAN 1 Cluring Banyuwangi. It is located at $\mathrm{Jl}$. Cluring Huzaini Benculuk Banyuwangi. In this research, the population is the teachers of SMAN 1 Cluring totaling 39 teachers with details of 31 PNS Teachers and 8 NonPermanent Teachers (GTT), while respondents who met the criteria were 31 people. To obtain respondents used purposive sampling technique. The criteria in determining the sample are (1) civil servants (2) have served at least 2 years. The purpose of determining criteria is to make the sample more homogeneous.

The variables were analyzed in this study are grouped into two types as follows:

Variables that will be analyzed in this study are grouped into two types as follows:

a. independent variable: the independent variable in this study was the Principal Managerial Competence (Komman), Motivation (Motiv), Work discipline (Dis).

b. dependent Variable: the dependent variable in this study was Performance (Kiner)

\section{Test of Validity and Reliability}

The measurement instrument can be said to be valid if the tool performs its size function or provides a measurement result that matches the measurement objective. Each item in the questionnaire is valid or not, can be known by confirming between item scores (rx) with a score of 0.3. The indicators of a variable are said to be valid if;

a. $r x<0.3$ means that each statement item in the questionnaire is invalid b. $r x>0.3$ means that each statement item in the questionnaire is valid

The instrument is said to be reliable if the results are consistent and can be used safely as it may work well at different times and different conditions, thus reliability indicates how large the measurement can provide a relatively no different results when carried out measurement again against the same subject. The value of the limit that is used to assess a reliability level can be known by way of confirming between the Cronbach's Coefficient Alpha $(\alpha)$ with a score of 0.6. Indicators of a variable is said to be reliable if;

a. $\alpha<0.6$ means an unreliable questionnaire

b. $\alpha>0.6$ means a reliable questionnaire

The analysis used by the researchers in this study is multiple regression analysis. The equations of multiple regression are:

$$
\text { Kinerit }=b_{0}+b_{1}+b_{2}+\text { Motivit }_{i t}
$$

Kommanit $+b_{3}$ Dis $_{i t}+e_{i t}$

Description:

Kinerit $=$ Performance

$\mathrm{b}_{0} \quad=$ Constant

$b_{1}, b_{2}, b_{3}=$ Linear Regression Coefficient of multiple

Komman $_{\text {it }}=$ the principal managerial Competencies

Motivit = Motivation

Dis it $_{\text {I }}=$ Discipline work

$\mathrm{e}_{\mathrm{it}} \quad=$ Error

\section{The Test of Hypothesis} T-test (partial Test)

The t-test is used to find out the influence of each variable (performance) against the free variables used to measure the problem formulation to 1 . Use of the level of significance in various t-test:

a) Ho: $\mathrm{bi}=0$

b) Ha: bi $\neq 0$,

1) If the significance value is $<0.05$, it can be said that there are partially significant effects between managerial competence, 
motivation, work discipline on performance, it means Ho is rejected.

2) If the significance value is $>0.05$, it means that there are no partially significant effects between managerial competence, motivation, work discipline on performance, it means Ho is received.

\section{F-test (test of simultaneous)}

The F-test is used to find out the influence of independent variables simultaneously on the dependent variable. Significant means relationships that occur can be applied to the population. The use of F-test levels of significance in a wide array of:

a) Ho: $b i=0$

b) Ha: one bi $\neq 0$,

1) If the significance value is $<0.05$, it can be said that there are partially significant effects between managerial competence, motivation, work discipline on performance, it means Ho is rejected.

2) If the significance value is $>0.05$, it means that there are no partially significant effects between managerial competence, motivation, work discipline on performance, it means Ho is received.

\section{RESULT ANALYSIS}

Test of validity and reliability of data are used in order the research instruments work properly, so the instruments used are valid and reliability. The instruments are said to be valid and reliable if it is able to measure what should be measured. The results of the test validity and reliability were about the managerial competence of the principal variables with 7 indicator and 15 questions items are gotten the correlation value ( $\left.\mathrm{r}_{\text {arithmetic }}\right)$. It was ranged about 0.528 up to 0.915 . The value of the range ( $\left.\mathrm{r}_{\text {arithmetic }}\right)$ was greater than 0.3 or $r_{\text {arithmetic }}>0.3$, so it could be be stated that the whole item question on managerial competence of the principal variables were valid. The value of the Cronbach's Coefficient Alpha $(\alpha)$ by 0.950 was larger than 0.60 or $\alpha>0.60$, that it colud be stated that the whole item question on managerial competence of the principal variables were reliability. The results of the test validity and reliability concerned a variable motivational work with 2indicators and 10 items of questions retrieved the value of the correlation $\left(r_{\text {arithmetic }}\right)$ range from 0.498 up to 0.865 . The value of the range $r_{\text {arithmetic }}$ was greater than 0.3 or $r_{\text {arithmetic }}>0.3$, so it could be stated that the whole items question on motivation variables were valid. The value of the Cronbach's Coefficient Alpha $(\alpha)$ of 0.914 was greater than 0.60 or $\alpha>0.60$, so that it could be stated that the whole item a question on motivation variables is reliability. The results of the test validity and reliability concerned a work discipline with 3 variable indicators and item 9 questions retrieved the value of the correlation $\left(\mathrm{r}_{\text {arithmetic }}\right)$ range from 0.461 up to 0.873 . The value of the range $r_{\text {arithmetic greater than } 0.3 \text { or }}$ $r_{\text {arithmetic }}>0.3$, so it could be stated that the whole item a question on work discipline were valid variables. The value of the Cronbach's Coefficient Alpha $(\alpha)$ was 0.875 , it was greater than 0.60 or Alpha $(\alpha)$ of $0.875>0.60$, so that it could be stated that the whole item a question on employment was a discipline of variable reliability.

Validity and reliability of testing results concerned the performance indicators with 3 variables and 3 items question obtained the value of the correlation ( $\mathrm{r}_{\text {arithmetic }}$ ) it was ranged from 0.878 up to 0.962 . The value of the range $r_{\text {arithmetic }}$ was greater than 0.3 . or $r_{\text {arithmetic }}>0.3$. So it could be stated that the whole item question on performance variables were valid. The value of the Cronbach's Coefficient Alpha $(\alpha)$ was 0.922 it was larger than 0.60 or Cronbach's Coefficient Alpha $(\alpha)$ was $0.922>0.60$, so that it couldbe stated that the whole item 
question on reliability performance was variable.

\section{Multiple Linear Regression Analysis}

The results of calculation of multiple linear regression analysis in this research used the help computer calculation program by using Statistical Product and Service Solution (SPSS) it was version 19.0. As for the recapitulation of multiple linear regression analysis results were presented in table 1.

Table 1 Recapitulation of Multiple Linear Regression analysis results

\begin{tabular}{|c|l|c|c|}
\hline No. & \multicolumn{1}{|c|}{ Variabel Bebas } & $\begin{array}{c}\text { Koefisien } \\
\text { regresi }\end{array}$ & Sign. \\
\hline 1. & The principal managerial competencies (komman) & 0,273 & 0,048 \\
2. & Motivation (motiv) & 0,396 & 0,014 \\
3. & Work Discipline (dis) & 0,443 & 0,016 \\
\hline Constants & $=-0,827$ \\
F-arithmetic & $=27,599$ \\
Significance & $=0,000$ \\
\hline
\end{tabular}

Source: Research data is processed

Based on the results of a multiple linear regression analysis regression equation was obtained as follows:

kiner $=-0.827+0.396$ komman +0.273

motiv +0.443 dis $(4.1)$

From equations (4.1) it could be seen the influence of the principal managerial competence variables, motivation and work discipline on performance.

\section{INTERPRETATION}

Hypothesis Testing Results of Regression Coefficients Partially with $t$ Test

To determine the effect of managerial variables, motivation, work discipline on the performance of partially used $\mathrm{t}$ test, where this test compares the significance value of more than $5 \%(0.05)$ or the significance value of less than $5 \%$ (0.05).

Table 2 Recapitulation of t- Test results

\begin{tabular}{|l|c|}
\hline \multicolumn{1}{|c|}{ Variabel } & Sig. \\
\hline The principal managerial competencies (komman) & 0,048 \\
Motivation (motiv) & 0,014 \\
Work Discipline (dis) & 0,016 \\
\hline
\end{tabular}

Source: Research data is processed

Based on table 2, the significance value of the managerial competence variable was 0.048 . So the significance was smaller than 0.05 or $0.048<0.05$. This indicates that the variable of principal managerial competence had significant influence on performance. The value of the variable on the significance of labor motivation was 0.014. Therefore, the significance was smaller than the value of 0.05 or $0.014<$
0.05. This shows that the motivation variable partially has a significant effect on performance. The significance value of the work discipline variable is 0.016 . It means the significance value was smaller than 0.05 or $0.016<0.05$. This shows that the work discipline variable has a significant influence on performance. 
The results of the regression Coefficient Hypothesis Test Simultaneously with the F-test

The $\mathrm{F}$ test is used to determine the effect on the principal's managerial competence variables, motivation, and work discipline on performance. Significant means that the relationships that occur can apply to populations.

Based on Table 2, the significance value of the principal's managerial competency variables, motivation, work discipline towards performance is 0,000 . Therefore, the significance value is smaller than 0.05 or $0.000<0.05$. This shows that simultaneously the principal's managerial competency variables, motivation, work discipline have a significant influence on performance.

This study shows that the influence of the principal's managerial competence, motivation, work discipline on teacher performance simultaneously. In carrying out its duties a school principal is required to have managerial competencies such as the principal as an educator, manager, administrator, supervisor, leader, innovator and motivator. The Principal provides guidance to teachers, employees and students. The Principal together with stake holders made Vision and Mission, empowered teachers in the implementation of work programs, program supervision, program evaluation and monitoring, administering program implementation and Documentation of the results of program implementation. The Headmaster makes a supervision program, carries out supervision. The Headmaster gives an example to the teacher, gives the right decision on each policy taken. The Principal provides new ideas in learning activities. The Principal gives awards and sanctions to the teacher, and creates a conducive work atmosphere.
Besides the principal managerial competencies, it was also supported by the motivation of teachers. Teachers were given the opportunity to Excel, get recognition from colleagues, friends to feel proud of his work as a teacher, get recognition from colleagues, receive a salary or honorarium each month, a pleasant working conditions, school leadership policy favors to all, and have a good relationship between colleagues (interpersonal) that can improve the performance of teachers. Work discipline as like the right time, doing the job efficiently, the high attendance rates, understand with the tasks that are carried out, responsible with his job done, execute carefully, work together with all parties, abiding by the rules that apply, and willing to accept sanctions if it violates the rules can improve the performance of teachers.From this it can be seen from some teachers who prepare learning devices such as RPP (plan of implementation of the study), Journal of teaching, syllabus, instructional media when the principal will perform supervision classes. When the teacher was given several tasks to be completed, the teacher could solve them with timely and the principal was satisfied with the results obtained. Any activity that was carried out was always administered and documented. Although there are still some teachers that their motivation was lacking and their discipline were also low, because there were still some teachers who were not able to finish the task on time, Principals were not satisfied with the results of the work of the teacher, there was the teacher that came late in school. The results of this research, the competency of the principal managerial, motivation, work discipline simultaneously influenced significantly to the teacher at performance at SMAN 1 Cluring, Banyuwangi.

CONCLUSION, IMPLICATION AND LIMITATIONS 


\section{Conclusion}

Based on the results of the analysis that had been done on this research, it could be concluded that: 1) the competence of principal managerial, motivation and work discipline partially has a significant effect on teacher performance at SMA Negeri 1 Cluring. 2) Principal managerial competence, motivation and work discipline simultaneously have a significant effect on teacher performance at SMA Negeri 1 Cluring. Thus the managerial competence of principals, motivation and work discipline has a significant effect on teacher performance at SMA Negeri 1 Cluring

\section{Implications}

The conclusion of the research results described above has a number of important implications for efforts to improve teacher performance in the achievement of the School Vision and Mission. The formulation of the implications of this study emphasizes efforts to increase perceptions of the principal's managerial competence, motivation, and work discipline on teacher performance in SMAN 1 Cluring, Banyuwangi.

The implication of research results on the problem of principal managerial competence, motivation, and work discipline in relation to teacher performance is that these three variables are apparently closely related to the teacher's performance. With good principals' managerial competence, teacher performance will also increase. For this reason the Principal is expected to increase the frequency of coaching to teachers, employees and students. Increase teacher empowerment in the implementation of work programs, program monitoring, program evaluation and monitoring, administration of program implementation and Documentation of the results of program implementation. It also needed to carry out supervision, give awards and sanctions to teachers, and create a conducive work atmosphere.

In order to increase teachers'

motivation, they must be given the opportunity for achievement. The teachers should be proud of their work, get pleasant working conditions, have a humble leader policy, and have a good relationship between colleagues (interpersonal) so it can improve teacher performance.

Work discipline must also be improved timely, as well as doing work efficiently, being responsible for the work done, carrying out tasks as well as possible, being able to cooperate with all parties, following the rules, and be willing to accept sanctions if they violate regulations so it can improve teacher performance.

\section{Limitation}

Based on the results of the research and conclusions, it can be suggested: 1) The manager (Principal) needs to continuously and consistently motivate the teachers to improve their performance. 2) The teacher must improve his discipline so that his performance will also increase.

\section{REFERENCES}

Dharma, Surya, 2009. Manajemen Kinerja, Yogyakarta : Pustaka Pelajar.

Fattah. 1999. Landasan Manajemen Pendidikan Remaja. Bandung: Rosda Karya.

Fathoni Abdurrahmat. 2006. Organisasi dan Manajemen Sumber Daya Manusia, Jakarta : PT Rineka Cipta.

Hasibuan. 2006. Manajemen Sumber Daya Manusia. Jakarta: PT Bumi Aksara. Jakarta

Husein Umar, 2002. Metode Riset Bisnis. Jakarta :PT. Gramedia Pustaka Utama. 
Meta, Nandha. 2013. Pengaruh Disiplin Kerja dan Kepemimpinan Terhadap Kinerja Karyawan Pada PT. Pustaka Rizki Putra Semarang. Tesis. Fakultas Ilmu Sosial dan Politik Universitas Diponegoro Semarang.

Mulyasa. 2009. Menjadi Kepala Sekolah Profesional. Bandung : PT Remaja Rosdakarya.

Peraturan Menteri Pendidikan Nasional Republik Indoesia Nomor 16 Tahun 2007 tentang Standar Kualifikasi Akademik dan Kompetensi

Rivai Veithzal. 2004. Manajemen Sumber Daya Manusia Untuk Perusahaan : Dari Teori Ke Praktik. PT. Raja Grafindo Persada, Jakarta.

Siagian, Sondang P. 1996. Teori dan Praktek Kepemimpinan. Jakarta: Rineka Cipta

Sinungan. 1997. Produktifitas Apa dan Bagaimana. Jakarta: Bumi Aksara.

Soejono. 1997. Sistem dan Prosedur Kerja. Jakarta: Bumi Aksara

Sulistyorini, 2001. Hubungan antara keterampilan Manajerial Kepala Sekolah dan Iklim Organisasi dengan Kinerja Guru. Ilmu Pendidikan.

Sutikno. 2015. Pengaruh Gaya Kepemimpinan, Motivasi Kerja dan Kompensasi Terhadap Kinerja Guru Melalui Kepuasan Kerja. Tesis. STIE Mandala Jember.

Syadan. G. 1996. Manajemen Sumber Daya Manusia (Human Resources Manajement). Jakarata: Djembatan

Tu'u, Tulus, 2004. Peran Disipiln Pada Perilaku dan Prestasi Siswa, Jakarta: Gramedia Widiasarana.

Undang-Undang Republik Indonesia Nomor 14 Tahun 2005 edisi 2009, Tentang Guru dan Dosen, Bandung, Depdiknas, Citra Umbara

Wahjosumidjo. 2005. Kepemimpinan

Kepala Sekolah. Jakarta: PT Raja Grafindo. Persada.

\section{BIOGRAPHY}

Author named Suryadi, who was born in Banyuwangi, June 10, 1979, the fifth child of 6 siblings, from the couple of $\mathrm{Mr}$. Mursam and Mrs. Markanti. He is a Moslem and living at Dusun Krajan RT. 04 RW II Siliragung village, Siliragung district, Banyuwangi regency.

Education ever undertaken by the author :

$\begin{array}{ll}\text { 1986-1992 } & \text { SDN IX Jajag-Banyuwangi } \\ \text { 1992-1995 } & \text { SMPN 2 Gambiran-Banyuwan } \\ \text { 1995-1998 } & \text { SMAN 1 Gambiran-Banyuwar } \\ 1998-2002 & \text { S1 degree of Physics Educatio }\end{array}$

Author's work experience :

2004-2005 Honorer teacher at MTs Neger

2005-2009 Teacher at MTs Mambaul Hu

2005-now Civil Servant teacher at SMAN 